\title{
How to balance eco-environmental improvement and investment shortage ----- practice from the eco-environmental public-private partnership projects in China
}

\author{
Yu Fan ${ }^{1,2}$, Yunhao Zhao*3,4, Lu Xin ${ }^{3,4}$, Jing $\mathrm{Lu}^{3,4}$, Shunqing $\mathrm{Xu}^{3,4}$, Zhijie $\mathrm{Xu}^{3}$ \\ ${ }^{1}$ School of Economics and Management, Beijing Information Science and Technology University, Beijing, 100192, P.R. China. \\ ${ }^{2}$ Laboratory of Big Data Decision Making for Green Development, Beijing Information Science and Technology University, Beijing, \\ 100192, P.R. China. \\ ${ }^{3}$ Eco-Environmental PPP Centre, Chinese Academy for Environmental Planning, Beijing, 100192, P.R. China. \\ ${ }^{4}$ Department of Public Finance and Investment Research, Chinese Academy for Environmental Planning, Beijing, 100192, P.R. China.
}

\begin{abstract}
Faced with the severe eco-environmental problems and economic slowdown, China started the exploration of public-private partnership mode on eco-environmental protection projects, aiming to solve the disbalance between environmental improvement and investment shortage. This study systematically analyzed the characteristics, policy and market reactions of eco-environmental protection public-private partnership projects since 2014. Till the end of 2018 in China, the number of eco-environmental protection public-private partnership projects was 2,914 and investment was 1.84 trillion RMB, accounting for 33.67\% and $13.94 \%$ of the total, respectively. The peak year was in 2017 , then the number of eco-environmental protection public-private partnership projects dropped significantly in 2018. It is estimated that from 2014 to 2018 , the investment from eco-environmental protection public-private partnership projects in the implementation phase contributes to $3.2 \%$ of China's GDP, $0.2 \%$ of economic growth. To some extent, it has accelerated the process of ecological and environmental governance in China, especially in the field of municipal environmental infrastructure construction and comprehensive environmental treatment. However, the expected effect of eco-environment improvement from eco-environmental protection public-private partnership projects is difficult to guarantee, with the absence of key mechanisms and policies.
\end{abstract}

\section{Introduction}

As economic growth slows around the world, there has been an increasing interest in the application of publicprivate partnership (PPP) mode for governments in both developed and developing countries (Reley et al., 2018, Sahrear, 2020, Koppenjan, 2015). Faced with the severe eco-environmental problems and economic slowdown, how to solve the problems that the demand for ecoenvironmental protection increasing while the investment shortage, China begun to explore the PPP mode in the field of ecological and environmental protection, aiming to broaden the channels of environmental investment and financing (An et al., 2018, Wu et al., 2018).

This study summarized China's eco-environmental protection PPP (short for EEP-PPP) project practices, including characteristics, policy and the market situation, put forward the achievement and the deficiency. This study may be helpful for other countries and regions to carry out the ecological environment governance project by PPP mode, and provide references of green economy policy making and financial mode choices for global ecological and environmental governance (Buso and Stenger ,2018).

\section{EPP-PPP PROJECTS SITUATION IN CHINA}

\subsection{Characteristics of EPP-PPP projects in China}

PPP mode has been developed for decades in China, but the use of PPP mode in eco-environment protection projects is a new thing, except in the field of municipal sewage and garbage. In order to strengthen the management of PPP projects, the Ministry of Finance (MOF) set up China Public-Private Partnership Center (CPPPC). According to the classification method in the CPPPC, the EEP-PPP projects are divided into seven groups, sewage treatment, comprehensive treatment, garbage disposal, waste to power, wetland conservation, biomass energy and others. Till the end of 2018, the number of EEP-PPP projects was 2,914, and the investment was 1.84 trillion Yuan, accounting for $33.67 \%$ and $13.94 \%$ of the total, respectively. As shown in Table.1, the peak year was reached in 2017, with policies influencing such as financial policy tightening and strict compliance review, the number and the scale

\footnotetext{
* Corresponding author: zhaoyh@caep.org.cn
} 
of EEP-PPP projects in CPPPC both dropped significantly in 2018.

Table.1 The investment and number of EEP-PPP projects in library and transaction

\begin{tabular}{|c|c|c|c|c|c|c|c|}
\hline Contents & & $\begin{array}{l}\text { before } \\
2014\end{array}$ & 2014 & 2015 & 2016 & 2017 & 2018 \\
\hline \multirow[t]{2}{*}{$\begin{array}{l}\text { EEP-PPP } \\
\text { in CPPPC }\end{array}$} & $\begin{array}{l}\text { Investment } \\
\text { scale } \\
\text { (billion yuan) }\end{array}$ & 22.177 & 59.134 & 357.036 & 366.091 & 808.662 & 224.507 \\
\hline & $\begin{array}{l}\text { Projects } \\
\text { numbers }\end{array}$ & 66 & 131 & 657 & 635 & 1084 & 341 \\
\hline $\begin{array}{l}\text { EEP-PPP } \\
\text { in market } \\
\text { (in }\end{array}$ & $\begin{array}{l}\text { Investment } \\
\text { scale (billion } \\
\text { RMB) }\end{array}$ & 8.275 & 458.37 & 217.04 & 210.08 & 311.39 & 29.507 \\
\hline transaction) & $\begin{array}{l}\text { Projects } \\
\text { numbers }\end{array}$ & 27 & 78 & 326 & 313 & 350 & 64 \\
\hline
\end{tabular}

Note: before 2014, the 66 projects were used modes such as BOT, TOT and BOO, in the field of municipal sewage and garbage disposal, after 2014, these projects were included in CPPPC of MOF.

As shown in Table.2, the number of sewage treatment EEP-PPP projects and comprehensive treatment EEP-PPP projects were both over 800, and the investment were both over 400 billion yuan, followed by garbage treatment and waste to power EEP-PPP projects.
These fields all have charging and subsidy mechanisms, which are the main promotion field of EEP-PPP, besides, the implementation of EEP-PPP projects in these fields is relatively fast.

Table 2. The investment and number of EPP -PPP projects in different fields

\begin{tabular}{|c|c|c|c|c|c|c|c|c|}
\hline Contents & & $\begin{array}{l}\text { sewage } \\
\text { treamen } \\
t\end{array}$ & $\begin{array}{l}\text { comprehensiv } \\
\text { e treatment }\end{array}$ & $\begin{array}{l}\text { Garbag } \\
\text { e } \\
\text { disposa } \\
1\end{array}$ & $\begin{array}{l}\text { waste } \\
\text { to } \\
\text { power }\end{array}$ & $\begin{array}{l}\text { we dand } \\
\text { conservatio } \\
\text { n }\end{array}$ & $\begin{array}{l}\text { biomas } \\
8 \\
\text { energy }\end{array}$ & Others \\
\hline \multirow[t]{2}{*}{$\begin{array}{l}\text { EEP-PPP } \\
\text { in CPPPC }\end{array}$} & $\begin{array}{l}\text { Investmen } \\
\text { t scale } \\
\text { (bitlion } \\
\text { RMB) }\end{array}$ & 446.061 & 969.189 & 130.549 & $\begin{array}{l}49.20 \\
8\end{array}$ & 73.768 & 1.316 & $\begin{array}{l}167.51 \\
7\end{array}$ \\
\hline & $\begin{array}{l}\text { Projects } \\
\text { numbers }\end{array}$ & 1226 & 841 & 432 & 104 & 82 & 5 & 224 \\
\hline $\begin{array}{l}\text { EEP-PPP } \\
\text { in market } \\
\text { (in } \\
\text { transaction }\end{array}$ & $\begin{array}{l}\text { Investmen } \\
\text { tscale } \\
\text { (billion } \\
\text { RMB) }\end{array}$ & 184.643 & 466.468 & 52.517 & $\begin{array}{l}23.20 \\
2\end{array}$ & 21.927 & 1.052 & 73.32 \\
\hline ) & $\begin{array}{l}\text { Projects } \\
\text { numbers }\end{array}$ & 468 & 376 & 150 & 44 & 20 & 4 & 96 \\
\hline
\end{tabular}

The unbalanced regional distribution of EPP-PPP projects is obvious. Based on the analysis of all EEPPPP projects in CPPPC, the investments are mostly concentrated in the east, central and southwest China, accounting for $25.92 \%, 25.51 \%$ and $18.52 \%$, respectively. Provinces with a total investment of more than 100 billion RMB included Henan, Hubei, Sichuan, Guangdong, Guizhou and Shandong. The investment scale of EPP-PPP projects in the above six provinces accounts for $47.59 \%$ of the total, and the number of projects accounts for $44.76 \%$ of the total.

As shown in Table.3, the BOT mode is widely used in EEP-PPP projects, accounting for $72.61 \%$ of the total number and $74.85 \%$ of total EEP-PPP investment. Government payments and viability gap funding remain the main return mechanisms in EEP-PPP projects. 


\begin{tabular}{|c|c|c|c|c|c|c|c|c|}
\hline & & BOT & $\begin{array}{l}\text { TOT+B } \\
\text { OT }\end{array}$ & TOT & ROT & $\mathrm{BOO}$ & $0 \& M$ & Others \\
\hline \multirow[t]{2}{*}{$\begin{array}{l}\text { EEP- } \\
\text { PPP in } \\
\text { CPPPC }\end{array}$} & $\begin{array}{l}\text { Investment } \\
\text { scale } \\
\text { (billion RMB) }\end{array}$ & 1375.42 & 117.963 & 37.399 & 25.72 & 17.657 & 4.484 & 258.957 \\
\hline & $\begin{array}{l}\text { Projects } \\
\text { numbers }\end{array}$ & 2116 & 185 & 124 & 97 & 50 & 20 & 322 \\
\hline $\begin{array}{l}\text { EEP- } \\
\text { PPP in } \\
\text { market }\end{array}$ & $\begin{array}{l}\text { Investment } \\
\text { scale (billion } \\
\text { RMB) }\end{array}$ & 603.414 & 61.445 & 19.072 & 11.080 & 9.742 & 0.415 & 116.96 \\
\hline $\begin{array}{l}\text { (in } \\
\text { transact } \\
\text { ion) }\end{array}$ & $\begin{array}{l}\text { Projects } \\
\text { numbers }\end{array}$ & 803 & 96 & 56 & 43 & 17 & 3 & 141 \\
\hline
\end{tabular}

\subsection{Policy for EPP-PPP projects in China}

From 2014 to 2018, 34 policies were published in China to regulate and promote the implementation of PPP projects. According to the functions of policies, 4 policies were issued to promote the cooperation between the government and private capital, 14 policies were issued to strengthen PPP process management, 7 policies were published to prevent the risks of cooperation between the government and private capital, and 9 policies were issued to encourage and promote PPP implementation in regions.

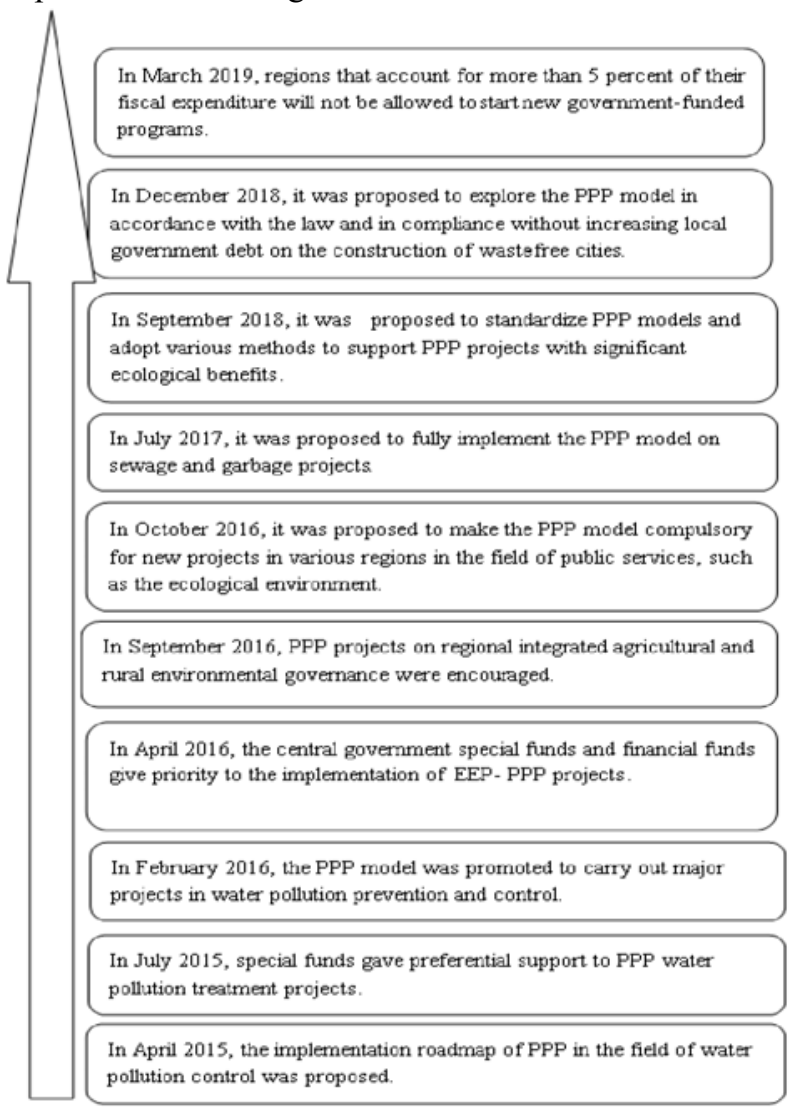

Fig. 1 Policy making of EEP-PPP in China

The main policies on the EEP-PPP projects were sorted out. In 2014, the policy on Guidance on innovating investment and financing mechanisms in key areas to encourage nongovernmental investment was published, which proposed further innovation of investment and financing mechanisms in key areas such as public services and infrastructure construction. Then in 2015, the policy on Guidance on promoting the model of cooperation between government and social capital in the field of public services was published, which means the scope of application PPP projects were extended from infrastructure to public services. In the field of ecology and environmental protection, the policy on Opinions on the implementation of public-private partnership (PPP) in water pollution prevention and control was published by the MOF together with the Ministry of Ecology and Environment of China. The PPP implementation roadmap on water pollution treatment was systematically, comprehensively and accurately presented in this policy. Then some policies were gradually published to make EEP-PPP projects bloom in China as shown in Fig.1. From 2014 to 2019, the aim of policies on EEP-PPP projects was from encouragement to enforcement the use of PPP mode in the ecoenvironmental field, till 2018, the policies gradually became tighten.

\subsection{Market reaction on EEP-PPP projects in China}

By the end of 2018, 1,158 EEP-PPP projects were completed, with a total investment of 882.29 billion RMB. Comprehensive treatment EEP-PPP projects had the largest investment scale, accounting for $56.74 \%$ of the total investment, followed by sewage treatment EEPPPP projects, accounting for $22.34 \%$. The investment in garbage treatment, waste to power, wetland protection and biomass energy projects was relatively small as shown in Table 2. Social capital from state-owned enterprises accounted for the highest proportion, with the investment of 559.028 billion RMB, accounting for $68.66 \%$ of the total transaction EEP-PPP projects. Private enterprises was important participants in EEPPPP market, with investment of 234.807 billion RMB, accounting for $28.84 \%$ of the total. The investment scale of EEP- PPP projects was relatively small, the investment scale under 500 million RMB accounted for more than $63 \%$ of the total. The EEP-PPP projects in the 
BOT mode accounted for $69.34 \%$ of the total number and $73.40 \%$ of the total investment as shown in Table 3 . As shown in Table 4, the number and scale of government-paid projects accounted for $46.63 \%$ and $52.42 \%$, respectively. The number and scale of viability gap funding projects accounted for $46.37 \%$ and $43.81 \%$.

Table.4 Return mechanism models in EEP-PPP projects

\begin{tabular}{|c|c|c|c|c|}
\hline & & $\begin{array}{c}\text { Paid by } \\
\text { government }\end{array}$ & $\begin{array}{c}\text { Viability Gap } \\
\text { Funding }\end{array}$ & User charges \\
\hline \multirow[t]{2}{*}{$\begin{array}{l}\text { EEP-PPP in } \\
\text { CPPPC }\end{array}$} & $\begin{array}{l}\text { Investment scale } \\
\text { (billion RMB) }\end{array}$ & 723.508 & 1009.935 & 104.165 \\
\hline & Projects numbers & 1111 & 1447 & 356 \\
\hline $\begin{array}{c}\text { EEP-PPP in } \\
\text { market }\end{array}$ & $\begin{array}{l}\text { Investment scale } \\
\text { (billion RMB) }\end{array}$ & 430.955 & 360.236 & 30.938 \\
\hline (in transaction) & Projects numbers & 540 & 537 & 81 \\
\hline
\end{tabular}

\section{ACHIEVEMENTS AND DEFICIENCY OF CHINA'S EEP-PPP PROJECTS}

\subsection{Achievements of EEP-PPP projects}

Firstly, to some extent, the promotion of EEP-PPP mode accelerated the process of ecological and environmental governance in China, especially in the field of municipal environmental infrastructure construction and comprehensive environmental treatment. In general, around one third of the projects were in EEP-PPP mode in the field of sewage treatment and garbage disposa in recent years. Secondly, it effectively supported China's ecological and environmental protection strategy. The EEP-PPP projects well supported the comprehensive treatment in river basins. By the end of 2018, there were 1,246 EEP-PPP projects related to ecological protection and restoration of the Yangtze river basin, and the investment was 812.985 billion RMB, accounting for $44.18 \%$ of the total investment in EEP-PPP project in CPPPC. Besides, it promoted multiple ecological and environmental management system. By the end of 2018, 984 enterprises participated in the EEP-PPP projects, among them, the number of state-owned and private enterprises accounted for $41.7 \%$ and $50.3 \%$, respectively. Finally, the EEP-PPP projects contributed to social and economic development. By the end of 2018, 929 companies were established by EEP-PPP projects, which played a positive role in promoting local economic development and employment. Using the national income method, it is estimated that the investment of EEP-PPP projects in the implementation phase directly contributed to $3.2 \%$ of China's GDP and $0.2 \%$ of economic growth from 2014 to 2018. If all the EEP-PPP project were in the implementation phase, the investment would contribute to $7.1 \%$ of China`s GDP and $0.5 \%$ of economic growth.

\subsection{Deficiency of EEP-PPP}

In practice, PPP participants such as the government and social capital tend to have a one-sided understanding of PPP. On the one hand, most governments only focus on the financing and construction, but tend to neglect of the assessment and supervision, which are important for PPP project implementation (Pagoni, 2019). Some local governments even break the contract and fail to pay the fees on time and in full, which has a bad impact on the follow-up implementation and promotion of EEP-PPP projects (Liu, 2019). On the other hand, social capital generally only focuses on investment return, with ignoring the quality and maintenance services. EEP-PPP projects have a characteristic with low benefits and public welfare, which could be greatly affected by policies. However, the social capitals tend to chase maximum return. Then in the absence of a sound supervision and restraint mechanism for social capital, the environmental benefits of the EEP-PPP project are difficult to guarantee. Besides, the characteristic indexes linked to the effect of eco-environmental governance were not paid much attention in the performance assessment of EEP-PPP project. Therefore, it is difficult to achieve the expected effect of eco-environmental improvement. Last but not least, the relevant policies on EEP-PPP are mainly on encouragement and promotion, few policies were implemented and actually worked. For example, the use of special funds was not flexible, which only focused on supporting the fixed assets investment in the early construction phase, then the special funds would be difficult to provide continuous financial support for the follow-up operation and maintenance of EEP-PPP projects.

\section{CONCLUSIONS}

Governments actively promoted the implementation of EEP-PPP projects in China since 2014. However, local governments tend to regard the PPP mode as a substitute for traditional financing platforms and a means of obtaining state policy support, then they not focus on their responsibilities in government management innovation and eco-environmental improvement in absence of key mechanisms and policies. Therefore, some suggestions were put forward to push the EEP-PPP projects return to the original intention. Firstly, performance management should become the focus of EEP-PPP projects, by establishing a payment mechanism completely linked to the output performance of the EEPPPP project, especially the eco-environment 
improvement performance throughout the operation and maintenance. Secondly, the policy on the character of EEP-PPP projects should be strengthened. The contribution of EEP-PPP projects to the prevention and control of pollution in China and the supporting role of EEP-PPP projects for environmental management system should both be strengthened. Because of the long operation period in PPP projects, good operation and maintenance are often the key to a win-win situation for PPP. Multiple models that focus on operations will be encouraged, for example the Design-Build-Operate

(DBO) model. Finally, at present, the number of EEPPPP projects by government payment or government subsidy accounted for $88 \%$ of total in the CPPPC. Turning government payment or subsidy into user payment or revenue feedback has become an important breakthrough and issue for sustainable EEP-PPP. In addition, we should positively encourage and explore the ways to promote the integrated PPP projects, combining the eco-environmental governance with eco-tourism, urban development or other industries, aiming to make ecological advantages into economic advantages. This would be a trend to solve the prominent problem of insufficient financial investment in environmental protection projects. Therefore, the integrated EEP-PPP projects focusing on the eco-environmental improvement should be gradually strengthened and promoted.

\section{References}

1. An X, Li H, Wang L, et al. 2018. Compensation mechanism for urban water environment treatment PPP project in China. Journal of Cleaner Production, 201: 246-253.

2. Buso M, Stenger A. 2018. Public-private partnerships as a policy response to climate change. Energy policy, 119: 487-494.

3. Koppenjan J F M. 2015. Public-private partnerships for green infrastructures. Tensions and challenges. Current Opinion in Environmental Sustainability, 12: 30-34.

4. Liu J, Liu J, Liu N. 2019.Government's control rights influence investor's escalation of commitment in PPP project: Regulating effect of other-face concern. Physica A: Statistical Mechanics and its Applications,

5. MOF (Ministry of Finance of People's Republic of China) ,2018. Website of China Public-Private Partnership Center (CPPPC), http://www.cpppc.org/ Note: Data as of October 31, 2018

6. Pagoni M E G G. 2019.A system dynamics model for the assessment of national public-private partnership programmes' sustainable performance. Simulation Modelling Practice and Theory, 101949.

7. Riley J H, Erpenbeck V J, Matthews J G, et al. 2018. U-BIOPRED: evaluation of the value of a publicprivate partnership to industry. Drug discovery today, 23(9): 1622-1634.

8. Sahrear C R, Haider M M. 2020. Growth Empirics of Public Private Partnership (PPP) in the Infrastructure Development of Bangladesh. International Supply Chain Technology Journal, 6(02).

9. $\mathrm{Wu} \mathrm{Y}, \mathrm{Xu} \mathrm{C}, \mathrm{Li}$ L, et al. 2018. A risk assessment framework of PPP waste-to-energy incineration projects in China under 2-dimension linguistic environment. Journal of Cleaner Production, 183: 602-617. 